\title{
Atypical Presentation of Sub Acutesclerosing Pan Encephalitis With Short Onset Latency
}

\author{
Wardhane $\mathbf{S}^{1}$, Oswal J2 , Shrivastava $\mathrm{K}^{3}$
}

\begin{abstract}
The most severe sequel of measles virus infection is sub acutesclerosing pan encephalitis (SSPE), a fatal disease of the central nervous system that generally develops 7-10 years after infection. A $71 \frac{1}{2}$ year old boy presented with gradual difficulty in walking and speech along with jerky movements of right upper limb which progressed to become generalized and progressive loss of cognition was also observed within days of onset of symptoms. Diagnosis of SSPE was made on the basis of burst suppression pattern on EEG and anti measles antibody in CSF. A differential diagnosis of SSPE should be considered in all forms of acute encephalopathy for early diagnosis and treatment.
\end{abstract}

\section{Introduction}

$S_{t}^{+}$ b acutesclerosing pan encephalitis (SSPE) is a progressive fatal disease of the central nervous system that is caused by a persistent measles virus infection. Early clinical characteristics of SSPE may be variable, but they often include behavioural changes, cognitive deterioration, sporadic episodes of falling, and such optic disturbances as chorioretinitis ${ }^{1,2}$. A 7 1/2 year old male child presented with history of gradual difficulty in walking and speech along with jerky movements of right upper limb, which then became generalized. A diagnosis of SSPE was made on the basis of EEG findings and presence of anti- measles antibody in CSF.

\section{The Case}

A $71 / 2$ year old male child was brought with complaints of gradually increasing difficulty in walking along with associated speech abnormality. He also had sudden jerky episodes of right upper limb which gradually progressed to generalized myoclonic spasms. He was drowsy irritable on presentation and responding to mother's voice but had increased tone in all four limbs and brisk reflexes, clonus was also observed. Gradually his cognition deteriorated and he stopped responding to any stimuli. He continued to have multiple episodes of myoclonus.

There was no significant past history or history of suffering from measles during childhood. Until onset of symptoms, child had apparently normal behavior and cognition. He was also vaccinated for age with all primary vaccines.
'Dr. Sneha Wardhane, MD, ${ }^{2}$ Dr. Jitendra Oswal Professor, ${ }^{3}$ Dr. Kavita Shrivastava, Associate Professor and Paediatric Neurologist. All from Bharati Hospital Pune, Maharastra, India.

Address for correspondence:

Dr. Sneha Wardhane

E-mail: drswardhane@gmail.com

\section{How to cite}

Wardhane S, Oswal J, Shrivastava K. Atypical Presentation of Sub Acutesclerosing Pan Encephalitis With Short Onset Latency. J Nepal Paediatr Soc 2015;35(1):62-63.

doi: http://dx.doi.org/10.3126/jnps.v35i1.10082

This work is licensed under a Creative Commons Attribution 3.0 License.

(c) (i)

Initially other causes for sudden onset weakness with myoclonus were evaluated. CSF and fundus examination was normal. EEG done was suggestive of periodic epileptic discharges, bilaterally symmetrical and synchronous. MRI brain was also suggestive of discrete hyper intensities in sub cortical white matter of bilateral frontoparietal regions, representing early changes of sub-acute sclerosing pan encephalitis. CSF for anti- measles antibody was reported positive. A diagnosis of atypical sub-acute sclerosing pan encephalitis was made as there is history of short onset latency.

Child was treated with Sodium valproate, Clonazepam and Amantidine, but continued to have episodes of myoclonus and there is no improvement in cognition observed. 


\section{Discussion}

Sub-acute sclerosing pan encephalitis is a progressive inflammatory disease of central nervous system caused by a persistent aberrant measles virus infection ${ }^{3}$. In the classical form of SSPE, slow progression of the disease through four characteristic stages is observed:

1. Slowly evolving behavioural and intellectual detoriation

2. Various types of involuntary movements

3. Severe pyramidal and extra pyramidal hypertonus and disappearance of hyperkinesias

4. Chronic vegetative state and death ${ }^{4,5}$.

Stage I may last from several weeks to years, stage II lasts from three months to one year. Stages III and IV last for a duration ranging from six months to one year ${ }^{4,5}$. But in a series by Risk and Haddad approximately $10 \%$ of patients had a fulminant progressive form ${ }^{6}$. Similarly Bonjinova et al in a 25 year epidemiology study found $10 \%$ of patients with a fulminant course ${ }^{7}$.

In early stages of SSPE, MRI shows lesions involving the parieto-occipital, cortico-subcortical regions asymmetrically. In time symmetric periventricular changes become more prominent, however MRI findings can be normal during early stages of disease ${ }^{8}$, as was observed in our patient. Diagnosis of SSPE is based on clinical findings, typical EEG changes (bilaterally symmetrical and synchronous periodic complexes) and elevated CSF titers of antimeasles antibody ${ }^{9,10}$.

Treatment for SSPE is still undetermined. Antiviral agents such as Amantidine, Ribavarin or immunomodulators like Isoprinosine, interferons, immunoglobulins, and corticosteroids have been used. However the results of the treatment of SSPE are not totally satisfactory ${ }^{11,12}$.

\section{Conclusion}

SSPE has recently been seen with more atypical symptoms and more acute, fulminant course. High index of suspicion should be present in patients with acute neurological signs like ataxia, dysarthria and inability to walk. Early diagnosis is important for the effectiveness of treatment.

\section{References}

1. GasconGG. Sub acutesclerosingpanencephalitis. SeminPediatrNeurol 1996;3:260-9.

2. Garg RJ. Sub acutesclerosingpanencephalitis. Postgrad Med J 2002;78:63-70.

3. Honarmand S, Glaser CA, Chow E et al. sub acutesclerosing pan encephalitis in the differential diagnosis of encephalitis. Neurology 2004;63:148993.

4. Adams RD, Victor M. Sub acutesclerosing pan encephalitis in: Lamsback WY; Navrozov M (eds). Principles of Neurology (5 $5^{\text {th }}$ edition) New York: McGraw Hill; 1993:656- 657.

5. Dyken PR. Viral diseases of the nervous system in: SwaimanKF (ed). Pediatric Neurology, Vol I. St Louis: CV Mosby; 1989: 499- 501.

6. Risk WS, Haddad FS. The variable natural history of sub acutesclerosing pan encephalitis: a study of 118 cases from the Middle East. Arch Neurol 1979;56:610-14.

7. BojinovaVS, Dirnova PS, Belopitova LD et al. clinical and epidemiological characteristics of sub acutesclerosing pan encephalitis in Bulgaria during the last 25 years (1978- 2002). Eur J PaediatrNeurol 2004;8:89-94.

8. Anlar B, Saatci I, Kose G, Yalaz K. MRI findings in sub acutesclerosing pan encephalitis. Neurology 1996;47:1278- 83.

9. Dyken PR. sub acutesclerosing pan encephalitis: Current status. NeurolClin 1985;3:179-96.

10. Griffin DE. Viral infections and related disorders in: ScheldWM, Whithley RJ, Durack DT (eds). Infections of the Central Nervous System; Philadelphia, New York: Lippincott- Raven 1997:47-57.

11. Anlar B, Yalaz K, Kose $G$ et al. beta interferon plus inosiplex in the treatment of sub acutesclerosing pan encephalitis. J Child Neurol 1998;13:557-59.

12. Tomoda A, Shiraishi S, Hosova M et al. combined treatment with interferon - alpha and ribavarin for sub acutesclerosing pan encephalitis. PediatrNeurol 2004;24:54-59. 